\title{
Analisis Strategi Pemasaran (Studi Kasus di Omaku Pusat Jajanan Tradisional, Kecamatan Kepanjenkidul, Kota Blitar)
}

\author{
Marketing Strategy Analysis (Case Study at Omaku Center for \\ Traditional Snacks, Kepanjenkidul District, Blitar City)
}

\author{
M. Halim Fawazi, SE., MM¹, Puji Rahayu ${ }^{2}$ \\ ${ }^{1}$ Fakultas Ilmu Sosial dan Politik, Universitas Islam Balitar \\ Jl. Majapahit No.2-4 Blitar, Indonesia \\ ${ }^{2}$ Fakultas Ilmu Sosial dan Politik, Universitas Islam Balitar \\ Jl. Majapahit No.2-4 Blitar, Indonesia \\ E-mail: mhalimfawazi@gmail.com
}

\begin{abstract}
ABSTRAK
Omaku Pusat Jajanan Tradisional merupakan salah satu industri rumah tangga dimana produk utamanya adalah jajan tradional seperti jajanan basah pada umumnya. Berawal dari dua orang loper keliling yaitu Ny Rusli Prijanto mulai mencoba untuk membuka usaha jajan basah.yang awalnya masih berlokasi di Jl. Anggrek 100 Blitar. Salah satu diferensial dari produk tersebut adalah resep jajanan basah tradisional buatannya yang khas dan terjamin serta stabil. Tujuan penelitian ini adalah untuk analisis dan menentukan strategi pemasaran yang dapat diterapkan pada Omaku Pusat Jajanan Tradisional. Analisis yang digunakan dengan pendekatan SWOT dan analisis deskriptif menggunakan pendekatan penelitian kualitatif terhadap responden yang diberi kuesioner yang mana responden tersebut dipilih dengan teknik purposive sampling. Untuk itu, dibutuhkan pengenalan kondisi perusahaan dan faktor internal maupun eksternal yang memiliki pengaruh terhadap strategi pemasaran. Untuk pengumpulan data dilakukan dengan wawancara, kuesioner dan observasi secara langsung. Disamping itu data dikumpulkan melalui data pendukung yang didapatkan dari buku, penelitian terdahulu dan sumber-sumber yang berhubungan. Data yang didapatkan berdasarkan data yang telah dikumpulkan selanjutnya dilakukan analisis dengan pendekatan SWOT agar dapat diketahui strategi pemasaran yang dapat digunakan berdasarkan dari kekuatan, kelemahan, peluang, serta ancaman perusahaan. Dari hasil penelitian menunjukkan bahwa matriks grand strategy perusahaan masuk dalam kuadran I, dimana implementasi strategi agresif atau bertumbuh merupakan kondisi yang sangat menguntungkan untuk perusahaan. Perusahaan mempunyai kekuatan sehingga mampu Dimana, perusahaan memiliki kekuatan sehingga dapat menggunakan peluang yang ada.
\end{abstract}

Kata Kunci : Analisis SWOT, Strategi Pemasaran dan Matriks Grand Strategy

ABSTRACT

Omaku Center for Traditional Snacks is one of the home industries where the main product is traditional snacks such as wet snacks in general. Starting 
from two peddlers, Mrs. Rusli Prijanto, started trying to open a wet snack business. Initially it was still located on Jl. Blitar 100 orchids. One of the differences of these products is the recipe for traditional wet snacks made which is distinctive and guaranteed and stable. The purpose of this study is to analyze and determine marketing strategies that can be applied to the Omaku Traditional Snack Center. The analysis used was the SWOT approach and descriptive analysis used a qualitative research approach to respondents who were given a questionnaire in which the respondents were selected by purposive sampling technique. For this reason, it is necessary to recognize the company's condition and internal and external factors that have an influence on the marketing strategy. For data collection, it was done by interview, questionnaire and direct observation. In addition, data is collected through supporting data obtained from books, previous research and related sources. The data obtained is based on the data that has been collected, then an analysis is carried out using a SWOT approach in order to find out which marketing strategies can be used based on the strengths, weaknesses, opportunities, and threats of the company. The results showed that the company's grand strategy matrix is included in quadrant I, where the implementation of aggressive or growth strategies is a very favorable condition for the company. The company has the power to be able to where, the company has the power so that it can use the existing opportunities.

\section{Keywords : SWOT Analysis, Marketing Strategy and Grand Strategy Matrix}

\section{PENDAHULUAN}

Salah satu peluang usaha yang semakin berkembang adalah industri rumahan, dikarenakan menipisnya lapangan pekerjaan yang tersedia. Industri rumahan seperti ini mudah dikelola karena pemantauan yang dilakukan bisa setiap saat. Industri rumahan seringkali dibangun atas dasar kekerabatan, dikarenakan membutuhkan permodalan yang tidak terlalu besar serta peralatan yang digunakan tidaklah rumit. Industri rumahan di Kota Blitar saat ini memang berkembang pesat karena dinilai bisa mendongkrak perekonomian bagi keluarga. Industri rumahan yang berkembang saat ini adalah industri dalam bidang makanan yang dianggap menjadi salah satu peluang usaha bagi masyarakat Kota Blitar. Hal ini terbukti munculnya produk jajanan tradisional yang hingga kini masih menjadi primadona bagi masyarakat.

Jajanan tradisional merupakan jajanan yang telah muncul dari zaman nenek moyang dulu serta jajanan yang pembuatannya dinilai sangat mudah karena tidak mebutuhkan modal besar serta tidak membutuhkan peralatan serta bahan yang rumit. Jajanan tradisional seperti jajanan basah sekarang sudah menjadi produk 
unggul di Kota Blitar hal ini terbukti dengan adanya event "Bazar Es Pleret Gempol" dan Jajanan Tradisioanal dalam rangka memeriahkan "SENAM TERA" yang diadakan Dinas Pariwisata dan Kebudayaan Kota Blitar dan juga event "Bazar Blitar Djadoel" yang diselenggarakan oleh Sekretariatan DPRD Kota Blitar. Event tersebut digelar untuk memasyaratkan kuliner asli Indonesia termasuk jajanan tradisional.

Perkembangan pesat yang dilalui jajanan tradisional di Kota Blitar ini tidak lepas dari tumbunya perekonomian dan cepatnya lingkungan berubah, sehingga mewajibkan perusahaan dapat dengan cepat mengontrol dan melakukan penyesuaian terhadap perubahan pasar. Dibutuhkan kreatifitas perusahaan untuk melakukan perancangan serta menentukan misi bisnis dan strategi pemasaran yang digunakan agar dapat memperhitungakn setiap perubahan yang terjadi dan mampu bersaing serta bergerak searah dengan kebutuhan konsumen. Hal ini perlu dilakukan dikarenakan pada dasarnya perusahan memiliki fungsi produksi barang serta jasa yang bisa diterima pelangganya sekaligus mampu mencukupi apa yang diinginkan oleh pelanggan, yang tujuanya adalah agar didapatkan keuntungan perusahaan sesuai dengan yang diinginkan. Agar tujuan tersbut dapat tercapai, maka perusahaan perlu mengadakan aktivitas pemasaran mengenai produk dan jasa yang ditawarkan.

Strategi merupakan suatu perencanaan terpadu dan berintegrasi yang dihubungkan dengan kelebihan perusahaan dengan tantangan lingkungan serta untuk menjamin terwujudnya tujuan perusahaan melalui ketepatan implementasi yang dilaksanakan oleh perusahaan. Strategi dengan kejelasan dan ketegasan bermanfaat dalam perumasan akan dapat merumuskan prediksi terhadap transformasi lingkungan dengan cepat dan tepat, terkait faktor-faktor dari dalam (internal) ataupun dari luar (eksternal) perusahaan. Hal ini berguna bagi perusahaan untuk pengambilan keputusan lebih awal terhadap perubahan lingkungan. Perusahaan yang mengalami peningatan persaingan dari masa ke masa salah satunya adalah usaha produksi ritel makanan. Disamping merumuskan strategi, diperlukan analisis yang dilakukan agar dapat membantu keberhasilan suatu rencana serta analisis yang dapat digunakan perusahaan ataupun badan usaha yakni analisis SWOT. 
SWOT analysis menurut Rangkuti (2006) merupakan pendekatan untuk mengidentifikasi beberapa aspek yang tersistematis guna merumuskan strategi perusahaan. Dasar dari analisis ini terdapat pada logika agar dapat dimaksimalkan Strengths (kekuatan), dan Oppurtunities (peluang), dan mampu diminimalisir Weaknesses (kelemahan) dan Threats (ancaman). Dari SWOT analysis mampu terwujud pemasaran yang baik. Pemasaran dapat dikatakan sebagi upaya agar dapat terpenuhi apa yang diinginkan dan dibutuhkan konsumen berdasarkan produksi barang ataupun jasa yang kemudian terjadi pembelian oleh konsumen melali suatu pertukaran. Pembuatan produk pada perusahan berdasarkan apa yang diinginkan dan dibutuhkan oleh pasar.

Omaku Pusat Jajanan Tradisional merupakan salah satu industri rumah tangga dimana produk utamanya adalah jajan tradional seperti jajanan basah pada umumnya. Berawal dari dua orang loper keliling yaitu Ny Rusli Prijanto mulai mencoba untuk membuka usaha jajan basah. Setelah merasa mampu dan optimis bahwa usahanya akan berkembang beliau mulai membuka toko kecil yang menjual jajan basah buatanya sendiri yang awalnya masih berlokasi di Jl. Anggrek 100 Blitar. Salah satu diferensial dari produk tersebut adalah resep jajanan basah tradisional buatannya yang khas dan terjamin serta stabil. Omaku sampai sekarang tetap mempertahankan keaslian dan kualitas resep Oma Kondang agar para konsumen tetap bertahan terhadap produk Omaku di zaman yang semakin maju dan semakin pesatnya pesaing.

Jajan-jajan basah tradisional dengan resep Oma Kondang terbuat dengan bahan yang berkualitas tinggi dan tetap menggunakan alat-alat tradisional untuk menjaga keaslian rasanya. Perlu diketahui rasa dari jajan basah ini sama seperti jajan basah pada umumnya dan dengan rupa yang sama. Untuk mewujudkan peningkatan daya saing, maka perusahaan harus mampu unggul dari kompetitor melalui produk yang berkualitas dan mampu memenuhi keinginan konsumen yang selalu mengalami perkembangan serta perubahan (Kotler dan Amstrong, 2004). Maka dari itu semakin berkembangnya penjualan di Indonesia dapat mengakibatkan perusahaan akan saling bersaing dengan ketat.

Peneliti memilih Omaku Pusat Jajanan Tradisional sebagai tempat penelitian karena sebagai industri rumahan yang sudah cukup lama dikenal 
masyarakat khusunya di Kota Blitar sangat berpotensi adanya pesaing yang memliki kesamaan produk. Maka dari itu peneliti mengamati bagaimana strategi pemasaran yang diterapkan oleh Omaku Pusat Jajanan Tradisional untuk berhadapan dengan kompetitor melalui penggunaan SWOT analysis. Beberapa aspek yang diperhatikan pada analisis ini yaitu external berdasarkan peluang dan ancaman, serta internal seperti kekuatan dan kelemahan. Hasil dari analisis yang dilakukan diharapkan dapat digunakan untuk penetapan strategi pemasaran secara tepat agar perusahaan mampu tetap eksis serta dapat membangun sebuah strategi memenangkan persaingan yang cocok dalam menemui segala kejadian perubahan terhadap lingkungan pada perusahaan.

\section{METODE PENELITIAN}

Lokasi penelitian yang dipilih merupakan bagian yang sangat penting pemilihannya karena harus ditemukan karakteristik dan kekhasannya, maka penelitian ini dilaksanakan di Omaku Jajanan Tradisional Jl. Melati 58. Kec Kepanjen Kidul. Kota Blitar. Waktu pelaksanaan dalam penelitian adalah tiga bulan yakni mulai tanggal 1 Maret - 30 Mei 2020 pada pukul yang bersifat kondisional. Untuk responden pada penelitian ini merupakan orang-orang yang berkaitan ataupun yang berhubungan dengan permasalahan yang diteliti oleh peneliti, yakni pengelola, 6 karyawan serta konsumen dari Omaku Jajajan Tradisional.

Yang menjadi definisi operasional yang dilakukan berdasarkan poin-poin utama pada analisis SWOT, diantaranya:

1) Strengths (kekuatan) termasuk pada kapasitas internal, sumber daya, serta aspek situasional positif yang mampu mendukung perusahaan dalam pelayanan konsumen dan untuk mencapai tujuan.

2) Weaknesses (kelemahan) merupakan batasan internal serta aspek situasional negatif yang menjadi penghalang kinerja peruasahaan.

3) Opportunities (peluang) dapat dikatakan sebagai faktor ataupun tren yang bermanfaat bagi lingkungan eksternal guna mendapatkan keuntungan perusahaan. 
4) Threats (ancaman) merupakan aspek dalam lingkungan eksternal yang tidak menguntungkan serta mendatangkan tantangan untuk perusahaan

Analisis dapat dikatakan sebagai sebuah metode yang dapat memberikan makna pada data guna pemecahan masalah penelitian yang memperhatikan kaitankaitan antara gejala yang selanjutnya dilakukan pemahaman-pemahaman terhadap hubungan antara kejadian setiap fenomena. Pada SWOT analysis di setiap tahapanya menggunakan seluruh data serta informasi pada pendekatan-pendekatan kuantitatif rumusan strategi. Dalam analisis SWOT sebelumnya dilaksanakan scanning atau pencermatan yang pada dasarnua adalah mendata dan mengidentifikasi untuk pra analisis. Pendektatan-pendekatan untuk menganalisis SWOT diantaranya sebagai berikut:

a. Internal Strategic Factory Analysis Summary (IFAS) dan Internal Strategic Factory Analysis Summary (EFAS)

\section{b. Space Matrix}

c. SWOT Matrix

Menganilis menggunakan lebih dari satu analisis akan lebih baik, sehingga perumusan strategi

Penggunaan beberapa analisis akan lebih baik sehingga menciptkana perumusan strategi yang mampu melakukan penyelesaian masalah dan strategi yang dibuat akan sesuai dengan tujuang dan lingkungan perusahaan.

\section{HASIL DAN PEMBAHASAN}

\section{Identifikasi Faktor Internal}

Untuk mengitenifikasi tingkat dari kekuatan dan kelemahan yang dimiliki pada Toko Omaku Pusat Jajanan Tradisional, Kota Blitar maka digunakan analisis terhdapa faktor internal.

a) Kekuatan (Strenght)

1. Produk berkualitas

2. Rasa yang tidak berubah

3. Tanpa pengawet

4. Perusahaan yang semakin berkembang

5. Perusahaan sudah dikenal masyarakat lokal 
b) Kelemahan (Weakness)

1. Pelayanan delivery order kurang

2. Lokasi kurang strategis

3. Kurangnya karyawan

4. Ketahanan jajan

5. Kurang berinovasi

\section{Identifikasi Faktor Eksternal}

Sedangkan untuk mengidentifikasi tingkat kekuatan peluang dan ancaman pada Toko Omaku Pusat Jajanan Tradisional, Kota Blitar maka digunakan analisis faktoer eksternal.

a) Peluang (Opportunities)

1. Kemajuan teknologi meningkatkan promosi

2. Loyalitas konsumen terhadap produk omaku

3. Daya beli masyarakat meningkat

4. Mengikuti Event

5. Tingkat permintaan produk tinggi

b) Ancaman (Threats)

1. Pesaing inovatif $\&$ variatif

2. Pesaing produk dengan harga lebih terjangkau

3. Pesaing dengan sistem online

4. Ketidak stabilan harga barang baku

5. Ketidak stabilan kondisi ekonomi masyarakat

\section{Identifikasi Bauran Pemasaran ( 7P)}

Kotler (2002) mengatakan bahwa bauran pemasaran diklasifikasi berdasarkan 4P, yakni Product, Price, Place, Promotion. Tetapi, Boom dan Bitner dalam Buchari Alma (2000) memodifikasi bauran pemasaran dengan menambahnya menjadi 3P, maka menjadi 7P yakni Product, Price, Place, Promotion, People, Physical Evidence Dan Process.

\section{a. Produk}

Produk dapat dikatakan sebagai segala sesuatu yang ditawarkan perusahaan 
dalam memperhatinkan, mencari, membeli, menggunakan ataupun mengkonsumsi pasar untuk menemukan apa yang dibutuhkan ataupun yang diinginkan pasar. untuk diperhatikan, diminya, dicari, dibeli, digunakan atau dikonsumsi pasar sebagai pemenuhan kebutuhan atau keinginan pasar yang bersangkutan (Tjiptono, 1999).

Untuk produk Toko Omaku sendiri beraneka macam, seperti mendut, nagasari dan jajan basah lainnya. Untuk bahan-bahan seperti pada jajan basah pada umumnya. Bentuk dan pengemasan juga masih sama seperti jajan basah pada umumnya. Rasa yang khas serta kualitas yang tetap stabil. Toko Omaku menyediakan jajan basah pembelian per biji dan juga pembelian dalam bentuk yang masih utuh, bentuk utuh yang dimaksudkan seperti wajik berbentuk persegi utuh yang belum dipotong menjadi bagian-bagian kecil.

\section{b. Harga}

Price atau harga merupakan sejumlah uang (apabila dimungkinkan menambah barang) yang diperlukan agar didapatkan sejumlah gabungan dari barang serta layanannya (Swastha dan Irawan, 2005). Toko Omaku dalam menetapkan harga memperhitungkan tenaga produksi dan bahan baku. Harga jajanan basah yang diproduksi sendiri oleh toko Omaku yaitu kisaran Rp 2000,s/d Rp 5000,- per pcs. Untuk jajan basah yang masih berbentuk utuh diberikan harga khusus dan beda dari harga pembelian per biji.

\section{c. Lokasi}

Lokasi usaha memelukan memerlukan perhatian khusus diantaranya saluran pendistribusian, kesedian barang dan transportasi yang merupakan lokasi dari tempat perusahaan beroperasi, memproduksi ataupun cara menyampaikan barang dari produsen ke konsumen. (Effendy, 1996). Lokasi Omaku yang kini di Jl. Melati no 58 di rasa kurang strategis karena lokasinya tidak di pusat kota. Tidak strategisnya lokasi yang baru ini mempengaruhi omset harian meski sudah mempunyai pelanggan tetap.

\section{d. Promosi}

Promotion atau promosi merupakan aktivitas atau segala upaya perusahaan untuk dapat mempengaruhi pelanggan secara aktual ataupun pelanggan potensial sehingga bersedia membeli produk yang ditawarkan sekarang ataupun yang akan 
datang (Sistaningrum, 2002). Toko Omaku melakukan promosi sekarang ini telah memanfaatkan sosial media, mengikuti event lokal, dan juga memanfaatkan fasilitas umum seperti pemasangan baliho dan spanduk.

\section{e. Orang / People}

Salah satu faktor penting dalam sebuah organisasi adala sumber daya manusia (SDM) disamping faktor lainya seperti permodalan. Maka dari itu diperlukan pengelolaan SDM yang baik sebagai upaya peningkatan organisasi agar efektiv dan efisien. (Hariandja, 2002). Karyawan Toko Omaku memiliki peran yang sangat penting, seperti tenaga produksi dan karyawan toko. Keduanya memiliki perang berbeda namun sama-sama berpengaruh. Tenaga produksi hanya mempunyai tugas menyiapkan, membuat dan menyiapkan jajan basah yang akan dijual. Lalu karyawan toko mempunyai tugas sebagai yang menerima pesanan, mempacking jajan basah serta yang berinteraksi langsung dengan konsumen.

\section{f. Proses atau Aktivitas Bisnis / Process}

Proses dapat dikatakan sebagai rangkaian tahapan untuk memulai aktivitas dari penentuan sasaran hingga penetapan pencapaian tujuan (Handayaningrat, 1988). Proses yang terjadi di Toko Omaku yaitu interaksi langsung dengan konsumen, dikarenakan produk jajan Omaku tidak dijual bebas diluar.

\section{g. Physical Evidence}

Bukti secara fisik adalah aspek penting dari sebuah jasa, oleh karena itu beberapa bagian produk jasa diperlukan terlihat secara nyata pada lingkungan jasa (Setyaningrum, 2015). Bukti fisik yang dimaksudkan adalah tester/sampel. Konsumen bisa merasakan langsung produk jajan basah Toko Omaku. Jadi konsumen bisa menilai langsung dan menilai ditempat bagaimana rasanya yang khas, citarasa yang tetap stabil serta produk yang berkualitas.

\section{Identifikasi Bobot dan Rating IFAS dan EFAS}

\section{a. Matriks IFAS}

Dalam menganalisis IFAS, matrik dibuat berdasarkan hasil mengidentifikasi faktor internal yakni strengths atau kekuatan serta weakness atau kelemahan yang memiliki pengaruh pada Omaku Pusat Jajanan Tradisional. Pemberian bobot didasarkan pada keunggulan relatif pesaing utama. Untuk memberi rating rating 
berdasarkan dari prediksi ataupun kesanggupan perusahaan untuk masa mendatang. Di bawah ini rumus penghitungan untuk memperoleh bobot dan rating.

Bobot $=\frac{\text { Jumlah nilai setiap pertanyaan/pernyataan }}{\text { Jumlah keseluruhan nilai }}$
Rating $=\frac{\text { Jumlah nilai setiap pertanyaan/pernyataan }}{\text { Jumlah responden }}$

Tabel 1. Hasil Penghitungan Bobot Faktor Internal

\begin{tabular}{|c|c|c|c|c|}
\hline Faktor Internal Kekuatan (Strenght) & $\begin{array}{l}\text { Jumlah } \\
\text { Nilai }\end{array}$ & Bobot & Rating & Skor \\
\hline 1. Produk berkualitas & 355 & 0,10 & 3 & 0,31 \\
\hline 2. Rasa yang tidak berubah & 341 & 0,10 & 3 & 0,30 \\
\hline 3. Tanpa pengawet & 367 & 0,11 & 4 & 0,43 \\
\hline $\begin{array}{l}\text { 4. Perusahaan yang semakin } \\
\text { berkembang }\end{array}$ & 334 & 0,10 & 3 & 0,29 \\
\hline $\begin{array}{l}\text { 5. Perusahaan sudah dikenal } \\
\text { masyarakat lokal }\end{array}$ & 363 & 0,11 & 4 & 0,42 \\
\hline \multicolumn{5}{|c|}{ Faktor Internal Kelemahan (Weakness) } \\
\hline 2. Pelayanan delivery order kurang & 364 & 0,11 & 4 & 0,42 \\
\hline 3. Lokasi kurang strategis & 319 & 0,09 & 3 & 0,28 \\
\hline 4. Kurangnya karyawan & 371 & 0,11 & 4 & 0,43 \\
\hline 5. Ketahanan jajan & 293 & 0,09 & 3 & 0,26 \\
\hline 6. Kurang berinovasi & 324 & 0,09 & 3 & 0,28 \\
\hline TOTAL & 3431 & $\mathbf{1 , 0 0}$ & 34 & 3,43 \\
\hline
\end{tabular}

Dapat terlihat pada tabel bahwa hasil yang didapatkan setelah dihitung menggunakan matrik IFAS didapatkan total skor pada Omaku Pusat Jajanan Tradisional sebesar 3,43. Karena skor bobot lebih dari 2,5 ini artinya menunjukkan bahwa posisi internal dalam perusahaan sangat kuat. Berdasarkan tabel 1 tersebut memperlihatkan bahwa kekuatan utama dari perusahaan adalah produk yang tidak menggunakan bahan pengawet (dengan nilai 0,43), dikarnakan masyarakat lokal telah mengenali produk omaku dengan baik sehingga mereka mampu menilai bahwa jajanan basah yang diproduksi oleh Omaku Pusat Jajanan Tradisional merupakan produk yang berkualitas dengan tetap menjaga keaslian 
rasa.

Kelemahan utama dari Omaku Pusat Jajanan Tradisional adalah ketahanan produk ( skor 0,26), memang betul karena pada dasarnya jajan basah bertahan dalam waktu kurang dari 24 jam. Mengingat semua produk Omaku Pusat Jajanan Tradisional tanpa memakai pengawet. Hal ini menyebabkan banyak konsumen yang mengeluh produk Omaku tidak bisa tahan lama sehingga mereka berasumsi bahwa sebaiknya memilih aneka jajanan modern yang bisa untuk menggantikan eksistensi dari jajanan basah.

\section{b. Matriks EFAS}

Untuk analisis matrik IFAS akan mengidentifikan berdasarkan faktor dari internal yakni opportunities (peluang) dan threat (ancaman) yang memiliki pengaruh pada Omaku Pusat Jajanan Tradisional. Dalam memberi bobot berdasarkan pada kemampuang relatif kompetitior utama. Untuk memberikan rating berdasarkan dari prediksi ataupun kesanggupan perusahaan pada masa mendatang. Dibawah ini rumus penghitungan untuk memperoleh bobot dan rating.

Bobot $=\frac{\text { Jumlah nilai setiap pertanyaan/pernyataan }}{\text { Jumlah keseluruhan nilai }}$
Rating $=\frac{\text { Jumlah nilai setiap pertanyaan/pernyataan }}{\text { Jumlah responden }}$

Tabel 2. Hasil Penghitungan Bobot Faktor Eksternal

\begin{tabular}{|l|c|c|c|c|}
\hline \multicolumn{1}{|c|}{$\begin{array}{c}\text { Faktor Eksternal Peluang } \\
\text { (Opporturnities) }\end{array}$} & $\begin{array}{c}\text { Jumlah } \\
\text { Nilai }\end{array}$ & Bobot & $\begin{array}{c}\text { Ratin } \\
\text { g }\end{array}$ & Skor \\
\hline $\begin{array}{l}\text { 1. Kemajuan teknologi meningkatkan } \\
\text { promosi }\end{array}$ & 364 & 0,10 & 4 & 0,40 \\
\hline $\begin{array}{l}\text { 2. Loyalitas konsumen terhadap produk } \\
\text { omaku }\end{array}$ & 350 & 0,10 & 3 & 0,30 \\
\hline 3. Daya beli masyarakat meningkat & 328 & 0,09 & 3 & 0,27 \\
\hline 4. Mengikuti Event & 365 & 0,11 & 4 & 0,44 \\
\hline 5. Tingkat permintaan produk tinggi & 334 & 0,09 & 3 & 0,27 \\
\hline \multicolumn{4}{|c|}{ Faktor Eksternal Ancaman (Threats) } \\
\hline 2. Pesaing inovatif \& variatif & 365 & 0,11 & 4 & 0,44 \\
\hline 3. Pesaing produk dengan harga lebih & 348 & 0,10 & 3 & 0,30 \\
\hline
\end{tabular}




\begin{tabular}{|l|c|c|c|c|}
\hline \multicolumn{1}{|c|}{ terjangkau } & & & & \\
\hline 4. Pesaing dengan sistem online & 357 & 0,10 & 3 & 0,30 \\
\hline 5. Ketidak stabilan harga barang baku & 333 & 0,09 & 3 & 0,27 \\
\hline $\begin{array}{l}\text { 6. Ketidak stabilan kondisi ekonomi } \\
\text { masyarakat }\end{array}$ & 340 & 0,09 & 3 & 0,27 \\
\hline TOTAL & $\mathbf{3 4 8 4}$ & $\mathbf{1 , 0 0}$ & $\mathbf{3 3}$ & $\mathbf{3 , 3}$ \\
\hline
\end{tabular}

Berdasarkan perhitungan di tabel 2 terlihat bahwa dalam penggunaan matrik EFAS didapatkan total nilai yang terdapat pada Omaku Pusat Jajanan Tradisional sebesar 3,3. Karena skor bobot lebih dari 2,5 ini artinya terindikasi bahwa perusahaan dapat dengan baik merespon faktor eksternal dengan menggunakan peluang untuk menghadapi ancaman. Perusahaan memiliki peluang adalah dengan mengikuti event-event (skor 0,44). Para konsumen mengakui bahwa dengan adanya event-event mereka dengan mudah menjumpai produk Omaku Pusat Jajanan Tradisional. Dengan adanya hal ini menyebabkan semakin tingginya loyalitas para konsumen dan permintaan produk Omaku Pusat Jajanan Tradisional juga semakin meningkat.

Ancaman utama dari Omaku Pusat Jajanan Tradisional adalah adanya pesaing yang inovatif dan variatif dalam mengembangkan produk jajanan basah (dengan nilai 0,44). Tentunya banyak kompetitor yang bergerak dibidang produksi makanan maka dibutuhkan inovasi dan perbanyak variasi meskipun soal rasa serta kualitas akan berbeda namun hal itu tetap menjadi ancaman bagi perusahaan.

\section{Matrik SWOT}

Berbagai alternatif strategi dilakukan perumusan didasarkan pendekatan analisis matrik SWOT. Keunggulan matrik tersebut adalah didapatkan secara mudah dengan diformulasikan strategi yang didapatkan berdasarkan penggabungan antara faktor internal dan eksternal. Terdapat 4 alternatif strategi yang menjadi saran, yakni SO Strategi, ST Strategi, WO Strategi dan WT Strategi. Matrik SWOT dianalisis digunakan data yang didapatkan dari hasil IFAS dan EFAS. 
Tabel 3. Matriks SWOT

\begin{tabular}{|c|c|c|}
\hline EFAS & $\begin{array}{l}\text { KEKUATAN (S) } \\
\text { 1. Produk berkualitas } \\
\text { 2. Rasa yang tidak } \\
\text { berubah } \\
\text { 3. Tanpa pengawet } \\
\text { 4. Perusahaan yang } \\
\text { semakin berkembang } \\
\text { 5. Perusahaan sudah } \\
\text { dikenal masyarakat } \\
\text { lokal } \\
\end{array}$ & $\begin{array}{l}\text { KELEMAHAN (W) } \\
\text { 1. Pelayanan delivery } \\
\text { order kurang } \\
\text { 2. Lokasi kurang } \\
\text { strategis } \\
\text { 3. Kurangnya karyawan } \\
\text { 4. Ketahanan jajan } \\
\text { 5. Kurang berinovasi }\end{array}$ \\
\hline $\begin{array}{l}\text { PELUANG }(\mathbf{O}) \\
\text { 1. Kemajuan teknologi } \\
\text { meningkatkan } \\
\text { promosi } \\
\text { 2. Loyalitas konsumen } \\
\text { terhadap produk } \\
\text { omaku } \\
\text { 3. Daya beli masyarakat } \\
\text { meningkat } \\
\text { 4. Mengikuti Event } \\
\text { 5. Tingkat permintaan } \\
\text { produk tinggi }\end{array}$ & $\begin{array}{l}\text { STRATEGI SO } \\
\text { 1. Meningkatkan } \\
\text { keloyalitasan } \\
\text { konsumen dengan } \\
\text { tetap menjaga kualitas } \\
\text { produk serta } \\
\text { kestabilannya. (S1, } \\
\text { S2,S3,O2,) } \\
\text { 2. Memanfaatkan } \\
\text { teknologi internet } \\
\text { sebagai media promosi } \\
\text { agar masyarakan diluar } \\
\text { Kota Blitar dapat } \\
\text { mengenali produk } \\
\text { Omaku. (S5,S4,O1) }\end{array}$ & $\begin{array}{l}\text { STRATEGI WO } \\
\text { 1. Menambah sarana dan } \\
\text { prasarana serta } \\
\text { personil karyawan } \\
\text { mengingat tingginya } \\
\text { permintaan produk } \\
\text { dari konsumen yang } \\
\text { cukup tinggi. (W1, } \\
\text { W3, O5,O3) } \\
\text { 2. Memanfaatkan event- } \\
\text { event lokal yang } \\
\text { biasanya berlokasi } \\
\text { strategis sekaligus } \\
\text { mempromosikan } \\
\text { perusahaan. (W2, O1, } \\
\text { O4) }\end{array}$ \\
\hline $\begin{array}{l}\text { ANCAMAN (T) } \\
\text { 1. Pesaing inovatif \& } \\
\text { variatif } \\
\text { 2. Pesaing produk } \\
\text { dengan harga lebih } \\
\text { terjangkau } \\
\text { 3. Pesaing dengan } \\
\text { sistem online } \\
\text { 4. Ketidak stabilan } \\
\text { harga barang baku } \\
\text { 5. Ketidak stabilan } \\
\text { kondisi ekonomi } \\
\text { masyarakat }\end{array}$ & $\begin{array}{l}\text { STRATEGI ST } \\
\text { 1. Membuat produk } \\
\text { berdasarkan bentuk } \\
\text { dan citarasa yang } \\
\text { baru. (S1,S2,S3,T1 } \\
\text {,T3) } \\
\text { 2. Dilakukan percobaan } \\
\text { agar diperoleh } \\
\text { alternatif bahan baku } \\
\text { yang memiliki } \\
\text { kualitas baik disaat } \\
\text { harga bahan baku } \\
\text { sedang tinggi. } \\
\text { (S1,T4,T5) }\end{array}$ & $\begin{array}{l}\text { STRATEGI WT } \\
\text { 1. Membuat produk } \\
\text { yang lebih bervariasi } \\
\text { dengan } \\
\text { menitikberatkan pada } \\
\text { bahan baku yang } \\
\text { berkualitas. (W5,T1) }\end{array}$ \\
\hline
\end{tabular}




\section{A. Strategi S-O (Strenghts-Opportunities)}

Untuk melakukan strategi ini didasarkan pada jalan pemikiran dari perusahaan yakni dengan menggunakan semua kekuatan untuk dimanfaatkan sebagai peluang. Omaku Pusat Jajanan Tradisional tetap menjaga produkproduknya agar tetap berkualitas, dengan kestabilan rasa serta produk yang aman tanpa bahan pengawet agar dapat meningkatkan loyalitas konsumennya. Dengan adanya kemajuan teknologi salah satunya dibidang internet bisa dimanfaatkan sebagai media untuk mempromosikan aneka produk Omaku Pusat Jajanan Tradisional, sehingga masyarakat diluar Kota Blitar juga bisa mengenalnya.

\section{B. Strategi W-O (Weaknesses-Opportunities)}

Penerapan dari strategi ini didasarkan dari memanfaatkan peluang yang dimiliki, dengan cara mengatasi kelemahan-kelemahan yang ada. Omaku Pusat Jajanan Tradisional sebaiknya menambah sarana dan prasarana agar dapat mengimbangi permintaan masyarakat yang semakin hari semakin tinggi seperti memfasilitasi karyawan dengan kendaraan perusahaan agar dapat menjalankan sistem delivery order, mendaftarkan produk -produk kepada kemitraan makanan yang berbasis online. Memanfaatkan event-event lokal yang yang diadakan pemerintah mapun nonpemerinah yang dapat meningkatkan volume penjualan produk serta sebagai ajang promosi dan pengenalan lebih lanjut tentang Omaku Pusat Jajanan Tradisional.

\section{Strategi S-T (Strenghts-Treathts)}

Menciptakan produk baru dengan citarasa yang baru dengan tetap mempertahan mutu serta kualitas mengingat maraknya para pesaing yang mempunyai kesamaan produk serta lebih bisa berinovasi. Produk baru harus mempunyai kualitas berdasarkan ciri khas yang sama dari produk-produk sebelumnya, kualitas produk didapatkan dari bahan baku yang memiliki kualitas terbaik. Saat harga bahan baku tidak stabil alangkah baiknya mencari alternatif suplier bahan baku yang baru.

D. Strategi W-T( Weaknesses-Treathts)

Menciptakan produk-produk yang lebih berinovasi dan lebih bervariatif degan bahan-bahan baku yang tetap berkualitas. Dengan begitu volume penjualan tetap bisa meningkat meski banyaknya pesaing dengan produk yang sama. 


\section{Analisis Matriks Grand Strategi}

Berdasarkan hasil analisis SWOT, maka menghasilkan perhitungan yang menggunakan grafik analisis $\mathrm{X}$ dan $\mathrm{Y}$ berikut ini:

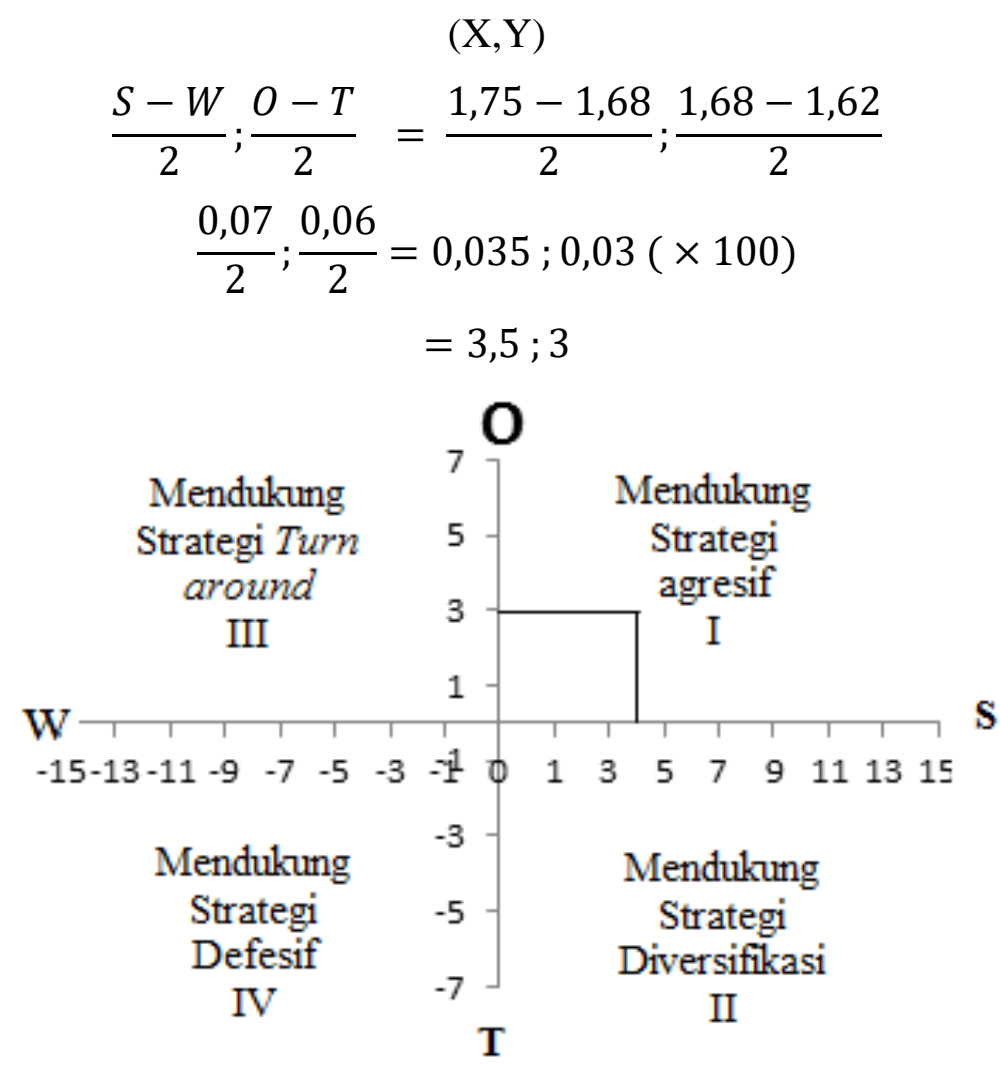

\section{Gambar 1. Matriks Grand Strategy}

Dari Grand Strategy tersebut, terlihat dengan jelas bahwa Omaku Pusat Jajanan Tradisional terletak di kuadran I dimana situasi yang sangat menguntungkan. Perusahaan ini terdapat peluang dan kekuatan sehingga diperlukan pemanfaatan peluang yang dimiliki. Untuk strategi yang perlu diiplementasikan pada keadaan tersebut adalah Strategy Agressive (bertumbuh).

Pada posisi kuadaran I dalam matrik Grand Strategy atau pada diagram SWOT diatas mengindikasikan bahwa suatau perusahaan memiliki pertumbuhan pasar yang tinggi dan berada pada kondisi kompetisi yang kuat dan perusahaan di kuadran ini memiliki posisi yang sangat bagus.

Dari hasil SWOT analysis didapatkan bahwa pada matrik IFAS memperlihatkan faktor kekuatan dan kelemahan mendapatkan nilai 3,43. Hasil tersebut menunjukkan adanya indikasi bahwa usaha yang dilakukan Omaku Pusat 
Jajanan Tradisional berada pada posisi internal dalam keadaan yang kuat. Kemudian, pada matrik EFAS memperlihatkan bahwa faktor peluang serta ancaman mendapatkan hasil akhir dengan nilai 3,3. Keadaan tersebut menunjukan indikasi bahwa Omaku Pusat Jajanan Tradisional mampu merespon peluang yang dimiliki melalui cara yang luar biasa dan menghindarkan ancaman yang ada pada pasar industri saat ini.

Sesudah menerapkan strategi SO atau menggabungkan kekuatan dan peluang, maka didapatkan faktor kekuatan yang harus dijaga agar dapat mendapatkan peluang yang ada. Penggabungan strategi ST memperlihatkan bahwa perusahaan perlu mengoptimalkan kekuatan agar dapat ancaman yang ada dapat teratasi. Untuk strategi WO, menggunakan peluang dengan cara memenimalisir kelemahan dari perusahaan. Serta pada strategi WT perusahaan harus dapat meminimalisir kelemahan dan menjauhi ancaman.

\section{KESIMPULAN DAN SARAN}

Berdasarakan hasil penelitian yang telah telaksana makakesimpulanya adalah sebagai berikut :

\section{Kekuatan (Strenght)}

Kekuatan dari Omaku Jajanan Tradisional yaitu berupa produk yang berkualitas lalu rasa yang tidak berubah, berbahan dasar tanpa pengawet, memiliki perusahaan yang semakin berkembang dan perusahaannya semakin dikenal oleh masyarakat luas.

\section{Kelemahan (Weakness)}

Kelemahan dari Omaku yaitu pelayanan delivery order yang dirasa kurang, lokasinya yang kurang strategis, minimnya tenaga kerja, ketahanan jajannya sangat minim dan kurangnya inovasi dalam produksi jajan basah.

3. Peluang (Opputunities)Kemajuan teknologi meningkatkan promosi

Peluang dari Omaku adalah loyalitas konsumen terhadap produk omaku, daya beli masyarakat semakin meningkat, sering kali mengikuti Event yang ada dan tingkat permintaan produk tinggi.

4. Ancaman (Treath)

Pesaing inovatif \& variatif Pesaing produk dengan harga lebih terjangkau Pesaing 
dengan sistem online Ketidak stabilan harga barang baku Ketidak stabilan kondisi ekonomi masyarakat

Dari penelitian yang telah dilakukan, peneliti mengusulkan beberapa saran, diantaranya :

1. Untuk Omaku Pusat Jajanan Tradisional dapat melaksanakan inovasi dan variasi produk berdasarkan rasanya, bentuknya, ataupun kemasanya, agar mampu meberikan daya tarik bagi pembeli.

2. Sebaiknya Omaku Pusat Jajanan Tradisional dapat ditambah lebih banyak lagi mitra kerja, dikarenakan hal tersebut dapat meberikan peningkatan omset penjualan.

3. Agar unggul dalam mempromosikan produk agar lebih baik dari kompetitor maka perusahaan dapat mengikuti perkembangan promsosi saat ini dengan digunakanya brand ambasador yang didapatkan dari artis ataupun publik figur seperti.

4. Untuk penelitiani selanjutnya, dari hasil penelitian yang telah dilakukan dapat dikembangkan dengan penelitian terkait strategi pemasaran berdasarkan SWOT analysis seta pendekatan yang lain.

\section{DAFTAR PUSTAKA}

Alma, Buchari. (2000). Manajemen Pemasasaran dan Pemasaran Jasa Edisi Revisi. Cetakan Keempat. Bandung: Alfabeta.

Effendy, Rustam. (1996). Marketing Management. Malang: IKIP Malang.

Handayaningrat, Soewarno. (1988). Pengantar Ilmu Administrasi dan Manajemen. Jakarta: CV Haji Masagung.

Hariandja, Marihat Tua Efendi. (2002). Manajemen Sumber Daya Manusia. Jakarta: Grasindo.

Kotler, Philip. (2002). Manajemen Pemasaran Edisi Millenium. Jakarta: PT Prenhallindo.

Kotler, Philip dan Amstrong, Gray. (2004). Dasar-Dasar Pemasaran Edisi ke-9, Jilid 1. Penerjemah Alexander Sindoro. Jakarta: PT Indeks.

Rangkuti, Freddy. (2006). Manajemen Strategis. Edisi Sepuluh. Jakarta: Penerbit Salemba Empat.

Setyaningrum, Ari. (2015). Prinsip-Prinsip Pemasaran. Yogyakarta: CV. Andi Offset.

Sistaningrum. (2002). Manajemen Penjualan Produk. Jakarta: Kanisius.

Swastha, Basu dan Irawan. (2005). Manajemen Pemasaran Modern. Yogyakarta: Liberti.

Tjiptono, Fandy. (1999). Strategi Pemasaran. Yogyakarta: ANDI. 